\title{
Uji Daya Hasil Lanjutan Galur-Galur Dihaploid Padi Sawah Hasil Kultur Antera
}

Yield Trial of Doubled Haploid Lines of Lowland Rice Obtained from Anther Culture

\author{
Santi Novita Sari dan Bambang Sapta Purwoko*
}

Departemen Agronomi dan Hortikultura, Fakultas Pertanian, Institut Pertanian Bogor (Bogor Agricultural University), Jl. Meranti, Kampus IPB Darmaga, Bogor 16680, Indonesia Telp. \& Faks.62-251-8629353 e-mail agronipb@indo.net.id

*Penulis Korespondensi : bambangpurwoko@gmail.com

Disetujui : 15 Januari 2018 / Published Online 23 Januari 2018

\begin{abstract}
The objective of this research was to evaluate yield of doubled haploid lines of lowland rice (Oryza sativa L.) obtained from anther culture and compare with control. There were 19 double haploid lines and 2 varieties as control, Inpari 13 and Ciherang. Experiment was replicated three times with randomized complete block design. This research was conducted at Babakan Experimental Station, Darmaga, Bogor and the nursery was conducted at Indonesian Center for Agricultural Biotechnology and Genetic Resources (BB BIOGEN) in December 2015-May 2016. The variable observed were plant height, number of tillers, days to flowering and harvest, panicle length, number of grains per panicle, number of filled grains per panicle, number of unfilled grains per panicle, percentage of filled and unfilled grains, weight of 1.000 grain, productivity and scoring bacterial leaf blight incidence. There were several lines resistant to bacterial leaf blight, such as CG9-26-1-5, CG9-33-1-4, CG9-53-1-3, HR2-6-1-1, HR3-6-2 -1, HR5-7-1-1 and HR5-9-1-1, however CG9-33-1-4 has the lowest productivity. Line CG12-30-1-3 had the highest productivity because number of filled grains and number of grains per panicle was high and weight of 1.000 grains about $27.35 \mathrm{~g}$. Line HR5-7-1-1 and HR3-10-1-1 had productivity over 4 ton ha $^{-1}$. Line HR3-10-1-1 was susceptible to bacterial leaf blight and weight of 1000 grains are low. Productivities of lines HR2-33-1-1, HR4-12-1-1, HR5-9-4-1 and HR5-13-2-2 between 3.68 to 3.93 ton ha ${ }^{-1}$, but HR4 -12-1-1 and HR5-13-2-2 were susceptible to bacterial leaf blight.
\end{abstract}

Keywords : dihaploid, line, lowland rice

\section{ABSTRAK}

Penelitian ini bertujuan menguji daya hasil galur-galur dihaploid padi sawah (Oryza sativa L.) hasil kultur antera dan membandingkannya dengan varietas pembanding. Terdapat 19 galur dihaploid padi sawah dan 2 varietas pembanding, Inpari 13 dan Ciherang. Percobaan diulang 3 kali dengan rancangan kelompok lengkap teracak. Penelitian dilaksanakan di Kebun Percobaan Babakan IPB, Darmaga, dan di Balai Besar Penelitian Bioteknologi dan Sumberdaya Genetik Pertanian, Cimanggu, Bogor, pada Desember 2015-Mei 2016. Pengamatan dilakukan terhadap karakter tinggi tanaman, jumlah anakan, umur berbunga dan panen, panjang malai, jumlah gabah per malai, jumlah gabah bernas/malai, jumlah gabah hampa/malai, persen gabah bernas dan hampa per malai, bobot 1.000 butir, produktivitas, serta scoring penyakit hawar daun bakteri. Terdapat beberapa galur yang tahan terhadap penyakit hawar daun bakteri, diantaranya galur CG9-26-1-5, CG9-33-1-4, CG9-53-1-3, HR2-6-1-1, HR3-6-2-1, HR5-7-1-1 dan HR5-9-11, namun galur CG9-33-1-4 memiliki produktivitas terendah. Galur CG12-30-1-3 merupakan galur dengan produktivitas tertinggi karena jumlah gabah bernas dan gabah total per malai tinggi serta bobot 1.000 butir yang berat yakni 27,35 g. Galur HR5-7-1-1 dan HR3-10-1-1 memiliki produktivitas lebih dari 4 ton ha ${ }^{-1}$, namun galur HR3-10-1-1 rentan terhadap penyakit hawar daun bakteri serta memiliki bobot 1.000 butir yang rendah. Galur HR2-33-1-1, HR4-12-1-1, HR5-9-4-1 dan HR5-13-2-2 memiliki produktivitas antara 3,68-3,93 ton ha ${ }^{-1}$, namun galur HR4-12-1-1 dan HR5-13-2-2 agak rentan terhadap penyakit hawar daun bakteri.

Kata kunci : dihaploid, galur, padi sawah 


\section{PENDAHULUAN}

Beras merupakan pangan pokok masyarakat Indonesia. Pertambahan penduduk yang terus meningkat menuntut adanya usaha peningkatkan produksi beras dalam negeri. Berdasarkan data di Balai Besar Penelitian Tanaman Padi (2014), produktivitas padi sawah jauh lebih tinggi dibanding padi lahan kering, sekitar 95\% produksi beras nasional dihasilkan dari usaha tani padi sawah. Berdasarkan data Kementan (2014), produktivitas padi sawah tahun 2012 sebesar 5.30 ton $\mathrm{ha}^{-1}$ dengan produksi padi nasional sebesar 69.06 juta ton, sedangkan tahun 2013 produktivitas padi sawah sebesar 5.32 ton ha $^{-1}$ dengan produksi padi nasional 71.29 juta ton. Upaya peningkatan produksi beras saat ini dibatasi oleh berbagai kendala, seperti konversi lahan sawah subur, anomali iklim, dan penurunan kualitas sumberdaya lahan (soil sickness) yang berdampak terhadap penurunan produktivitas. Tahun 2015, Indonesia dihadapkan pada kondisi kekeringan yang cukup panjang akibat perubahan iklim yang disebabkan oleh El nino, sehingga dibutuhkan varietas padi sawah yang toleran terhadap cekaman kekeringan disamping memiliki potensi hasil yang tetap tinggi.

Upaya peningkatan produktivitas padi dapat dilakukan melalui program pemuliaan tanaman. Salah satu hasil program pemuliaan tanaman di Indonesia ialah padi varietas unggul baru (VUB). Solusi ini dinilai cukup efektif karena padi VUB memiliki potensi hasil lebih dari 5 ton $\mathrm{ha}^{-1}$, tahan serangan organisme pengganggu tanaman (OPT), umur genjah serta memiliki kualitas beras dan bentuk biji yang sesuai dengan selera konsumen (Dewi dan Purwoko, 2012). Varietas unggul dapat diperoleh melalui pemuliaan konvensional. Pertanaman F1 hasil persilangan antara tetua akan menghasilkan progeni yang bersegregasi. Progeni-progeni yang mendekati homozigos akan diperoleh pada generasi ke-8 (F8), sehingga dibutuhkan waktu 710 tahun untuk memperoleh varietas unggul dengan teknik pemuliaan konvensional. Alternatif untuk mendapatkan varietas unggul dalam waktu yang relatif singkat, yakni melalui teknik kultur antera padi. Kultur antera merupakan salah satu teknik kultur jaringan yang dapat mempercepat proses mendapatkan galur homozigos melalui penggandaan kromosom spontan.

Keberhasilan kultur antera dipengaruhi oleh beberapa hal, yaitu komposisi media, praperlakuan eksplan, genotipe tanaman, lingkungan, dan stadia eksplan (Dewi et al., 2004). Produksi tanaman dihaploid melalui kultur antera secara in vitro merupakan salah satu teknologi yang sangat mendukung usaha perbaikan dan peningkatan hasil bagi berbagai jenis tanaman, termasuk padi (Dewi dan Purwoko, 2012). Teknik ini dapat memperoleh galur murni dengan lebih cepat jika dibandingkan dengan teknik konvensional yang membutuhkan waktu relatif lama.

$$
\text { Penelitian Putri (2014) dan Gunarsih }
$$

(2015) melalui teknik kultur antera telah menghasilkan galur-galur dihaploid padi. Tetua galur-galur ialah hasil persilangan padi gogo dengan padi sawah atau kedua tetua padi sawah. Galur-galur ini perlu diteliti lebih lanjut untuk mempelajari karakter unggul yang terdapat pada galur tersebut serta diharapkan memiliki produktivitas yang lebih baik dibanding varietas padi sawah pada umumnya namun dapat ditanam di lahan sawah tadah hujan. Penelitian Anindyajati (2015) melaporkan galur-galur yang memiliki umur berbunga dan umur panen lebih singkat serta persentase gabah bernas yang lebih banyak dibandingkan dengan varietas kontrol, yakni Inpari 13, Ciherang dan Situ Bagendit. Penelitian Khafiya (2015), melaporkan galurgalur dihaploid padi sawah dari hasil kultur antera yang memiliki keragaan berbeda-beda dengan produktivitas berkisar antara $4.5-5.6$ ton $\mathrm{ha}^{-1}$. Galur-galur tersebut telah dikarakterisasi dan perlu dilakukan pengujian lanjutan. Pengujian daya hasil merupakan aspek penting dalam mendapatkan varietas yang berdaya hasil tinggi. Penelitian ini bertujuan untuk menguji daya hasil galur-galur dihaploid tanaman padi sawah hasil kultur antera serta mendapatkan galur padi sawah yang berdaya hasil tinggi.

\section{METODE PENELITIAN}

Penelitian ini dilaksanakan di Kebun Percobaan Babakan, Darmaga, Bogor. Persemaian dilakukan di Balai Besar Penelitian Bioteknologi dan Sumberdaya Genetik Pertanian, Cimanggu, Bogor. Penelitian dimulai pada bulan Desember 2015 - Mei 2016. Terdapat 19 galur padi sawah yang diuji, yakni : CG9-26-1-5, CG9-27-1-2, CG9-33-1-4, CG9-53-1-3, CG12-30-1-2, CG1230-1-3, HR2-6-1-1, HR2-27-1-1, HR2-33-1-1, HR3-6-2-1, HR3-10-1-1, HR4-12-1-1, HR4-12-12, HR5-7-1-1, HR5-9-1-1, HR5-9-4-1, HR5-13-22, HR6-5-1-1, HR6-5-1-2 dengan dua varietas control yakni Inpari 13 dan Ciherang. Bahan lain yang digunakan untuk penelitian ini adalah pupuk sumber NPK dengan dosis masing-masing sebesar $200 \mathrm{~kg} \mathrm{ha}^{-1}$ Urea, $150 \mathrm{~kg}$ ha=-1 SP-36, $100 \mathrm{~kg} \mathrm{ha}^{-1}$ $\mathrm{KCl}$, serta pestisida berbahan aktif Dimethoate dan Isoprothiolane. 
Penelitian dirancang menggunakan Rancangan Kelompok Lengkap Teracak (RKLT) dengan galur sebagai faktor tunggal. Perlakuan terdiri atas 19 galur dihaploid hasil kultur antera padi dan 2 varietas kontrol. Setiap perlakuan diulang sebanyak $3 \mathrm{kali}$, sehingga terdapat 63 satuan percobaan. Satu satuan percobaan ialah petak berukuran $3 \mathrm{~m} \times 3.5 \mathrm{~m}$ dengan jarak tanam $25 \mathrm{~cm} \times 25 \mathrm{~cm}$. Tanaman contoh yang diambil secara acak dalam satuan percobaan sebanyak 5 tanaman. Data yang diperoleh dianalisis menggunakan analisis ragam dengan uji $\mathrm{F}$ pada taraf nyata 5\%. Jika uji nilai $\mathrm{F}$ berpengaruh nyata maka nilai tengah diuji lanjut dengan uji DMRT pada taraf nyata $5 \%$.

Penyemaian dilakukan pada bak semai sejumlah 63 satuan percobaan. Bak semai diisi dengan tanah 2/3 dari volume bak. Benih disebar merata dan ditutup tipis menggunakan tanah, kemudian disiram sampai lembab. Penyiraman dilakukan setiap hari sampai bibit siap dipindahkan ke sawah (19 hari setelah semai) untuk menjaga benih agar tidak kekeringan dan ketersediaan air untuk bibit tercukupi. Persiapan lahan meliputi pembersihan lahan dan pengolahan tanah. Bibit dari persemaian ditanam pada petakan dengan kedalaman 3-5 cm sebanyak 2-3 bibit tiap lubang tanam. Pupuk yang digunakan adalah Urea, SP-36 dan $\mathrm{KCl}$ dengan dosis masingmasing sebanyak $200 \mathrm{~kg} \mathrm{ha}^{-1}, 150 \mathrm{~kg} \mathrm{ha}^{-1}$, dan 100 $\mathrm{kg} \mathrm{ha}{ }^{-1}$. Pemupukan dilakukan dengan cara disebar dalam 3 tahap, yaitu (1) pada satu minggu setelah tanam (1 MST) berupa $40 \mathrm{~kg} \mathrm{ha}^{-1}$ Urea, $150 \mathrm{~kg} \mathrm{ha}^{-1} \mathrm{SP}-36$, dan $100 \mathrm{~kg} \mathrm{ha}^{-1} \mathrm{KCl}$, (2) pada 4 MST sebanyak $80 \mathrm{~kg} \mathrm{ha}^{-1}$ Urea, dan (3) pada 7 MST sebanyak $80 \mathrm{~kg} \mathrm{ha}^{-1}$ Urea.

Penyulaman dilakukan pada 2 MST. Pengendalian terhadap gulma dengan cara penyiangan dilakukan pada umur 3 MST dan 6 MST. Pengendalian terhadap hama keong dilakukan secara manual dan kultur teknis, sedangkan pengendalian terhadap hama belalang dan walang sangit serta penyakit dilakukan secara kimia dengan menyemprotkan pestisida. Panen dilakukan apabila 90\% malai sudah menguning atau sekitar 26-30 hari setelah berbunga dengan memotong batang kira-kira $20-40 \mathrm{~cm}$ di atas permukaan tanah menggunakan sabit. Panen pertama pada tanaman contoh, kemudian diikuti dengan pemanenan pada petakan bersih. Hasil panen dibedakan per satuan percobaan untuk memudahkan pengamatan pada komponen hasil, kemudian dilakukan pengiringan untuk merontokkan gabah.

Pengamatan dilakukan pada 5 rumpun tanaman contoh berdasarkan Panduan Sistem Karakterisasi dan Evaluasi Tanaman Padi
(Deptan, 2003) dengan komponen pengamatan sebagai berikut:

1. Tinggi tanaman generatif $(\mathrm{cm})$, diukur dari permukaan tanah sampai ujung malai tertinggi. Pengukuran dilakukan pada saat menjelang panen

2. Jumlah anakan produktif (batang/rumpun), diamati pada saat menjelang panen

3. Umur berbunga, dihitung dari saat menanam benih sampai $50 \%$ malai dalam satu rumpun telah keluar

4. Umur panen, dihitung dari saat menanam benih sampai $90 \%$ malai telah menguning

5. Panjang malai $(\mathrm{cm})$, diukur dari leher malai sampai ujung malai dengan mengambil 5 malai per rumpun contoh

6. Jumlah gabah total/malai, gabah bernas/malai, dan gabah hampa/malai (butir). Pengamatan dilakukan dengan menghitung jumlah gabah total, gabah bernas, dan gabah hampa dari tiap malai sebanyak 5 malai per rumpun contoh. Pengamatan dilakukan setelah panen

7. Persentase gabah bernas/malai (\%). Pengamatan dilakukan dengan membandingkan antara jumlah gabah bernas per malai dengan jumlah gabah total per malai dikalikan 100

8. Persentase gabah hampa/malai (\%). Pengamatan dilakukan dengan membandingkan antara jumlah gabah hampa per malai dengan jumlah gabah total per malai dikalikan 100

9. Bobot 1000 butir diperoleh dengan menimbang 1000 butir gabah bernas yang diambil secara acak dengan kadar air $\pm 14 \%$. Pengamatan dilakukan setelah gabah dikeringkan melalui penjemuran dengan matahari selama \pm 4 hari

10.Produktivitas per hektar, dihitung dari pembagian bobot total yang telah ditimbang dengan jumlah rumpun bersih dan dikonversikan dengan jumlah populasi per hektar

11.Scoring penyakit hawar daun bakteri (IRRI,1996)

\section{HASIL DAN PEMBAHASAN}

\section{Kondisi Umum}

Pertumbuhan awal pada masa vegetatif dari semua galur dihaploid dan varietas pembanding yang diuji terhambat oleh hama keong yang menyerang hingga 2 minggu setelah tanam (MST). Pengendalian dilakukan secara manual dengan memungut keong menggunakan tangan, serta dilakukan pengendalian kultur teknis 
dengan cara mengatur penggenangan air sawah hingga 4 MST. Hama lain yang mengganggu pada fase vegetatif ialah belalang. Pada fase pembungaan, beberapa galur terserang penyakit hawar daun bakteri.

Penyakit ini disebabkan oleh bakteri Xanthomonas oryzae pv. oryzae. Gejala infeksi awal berwarna hijau pucat sampai hijau keabuabuan, dimulai dekat ujung daun atau pinggir daun dan berkembang ke arah bawah dan luar daun. Munculnya penyakit ini disebabkan oleh tingginya curah hujan, lama penyinaran dan intensitas penyinaran yang relatif rendah, serta pengaruh posisi petakan. Penyakit hawar daun bakteri dapat menurunkan hasil produksi padi sampai $60 \%$ (Khaeruni, 2001). Pengendalian dilakukan secara kimiawi menggunakan pestisida berbahan aktif isoprothiolane. Penyemprotan dilakukan pada 51 HST. Hama yang menyerang setelah fase pembungaan adalah walang sangit dan burung pipit. Serangan kedua hama ini memuncak pada saat gabah dalam keadaan masak susu. Pengendalian terhadap hama walang sangit menggunakan insektisida berbahan aktif dimethoate, sedangkan serangan hama burung pipit ditanggulangi dengan pemasangan jaring di seluruh petakan. Curah hujan selama penelitian berlangsung berkisar 415-644 $\mathrm{mm}$ per bulan. Riwayat lahan pada petak ulangan berbeda, sehingga mempengaruhi pertumbuhan dan perkembangan tanaman. Petak ulangan 1 terletak di dekat sumber air. Petak ulangan 2 lebih dekat dengan rumah kaca. Petak ulangan 3 dekat dengan lahan tidak terpakai serta lapisan bajak tidak terbentuk sempurna sehingga lebih cepat kehilangan air.

\section{Keragaan Karakter Galur Dihaploid}

Keragaan karakter 19 galur dihaploid dan 2 varietas pembanding diuji menggunakan sidik ragam sebanyak 12 karakter.

Tabel 1. Hasil rekapitulasi sidik ragam

\begin{tabular}{lccc}
\hline \multicolumn{1}{c}{ Karakter } & Kuadrat Tengah & F Hitung & Koefisien Keragaman (\%) \\
\hline Tinggi tanaman fase generatif & 488.01 & $14.49^{* *}$ & 5.12 \\
Jumlah anakan produktif & 14.26 & $4.86^{* *}$ & 12.39 \\
Umur berbunga & 32.27 & $21.18^{* *}$ & 1.57 \\
Umur panen & 27.45 & $18.01^{* *}$ & 1.15 \\
Panjang malai & 4.05 & $15.89^{* *}$ & 2.01 \\
Jumlah gabah bernas per malai & 792.79 & $79.59^{* *}$ & 2.64 \\
Jumlah gabah hampa per malai & 788.81 & $21.50^{* *}$ & 12.02 \\
Jumlah gabah total per malai & 1.169 .28 & $31.22^{* *}$ & 3.60 \\
Persentase gabah bernas per malai & 183.79 & $27.00^{* *}$ & 3.69 \\
Persentase gabah hampa per malai & 183.79 & $27.00^{* *}$ & 8.92 \\
Bobot 1.000 butir & 12.79 & $66.42^{* *}$ & 1.80 \\
Produktivitas per ha & 0.91 & $3.15^{* *}$ & 14.92 \\
\hline Keterangan : **berpengaruh sangat nyata pada taraf $1 \% ; *$ berpengaruh nyata pada taraf 5\%; & & tidak berpengaruh nyata pada taraf 5\%.
\end{tabular}

Hasil pengujian sidik ragam (Tabel 1) menunjukkan bahwa genotipe berpengaruh sangat nyata terhadap seluruh karakter yang diuji dengan koefisien keragaman (KK) berkisar 0,64-14,92\%. Menurut Gomez dan Gomez (1996), semakin tinggi nilai KK maka unit percobaan yang digunakan makin tidak homogen.

\section{Tinggi Tanaman, Jumlah Anakan, Umur Berbunga, dan Umur Panen}

Hasil analisis pada Tabel 2 menunjukkan bahwa varietas Inpari 13 dan Ciherang merupakan varietas dengan tinggi tanaman sedang. Sebanyak 8 galur pada fase generatif yang memiliki tinggi tanaman nyata lebih tinggi dibanding varietas
Inpari 13 dimana galur CG9-26-1-5, CG12-30-12, CG12-30-1-3, dan HR4-12-1-2 termasuk kelompok padi dengan tinggi sedang, serta galur HR2-27-1-1, HR3-10-1-1, HR6-5-1-1, dan HR65-1-2 termasuk kelompok padi tinggi. Galur HR310-1-1 merupakan yang tertinggi diantara semua galur dihaploid dan varietas pembanding. Berdasarkan panduan Deptan (2003) tinggi tanaman padi pada fase generatif dibagi menjadi 3 kelompok, yaitu tanaman pendek yang memiliki tinggi $<90 \mathrm{~cm}$, tanaman sedang antara $90-125 \mathrm{~cm}$, dan tanaman tinggi $>125 \mathrm{~cm}$.

Tinggi tanaman merupakan salah satu karakter penting dalam pembentukan varietas padi. Pertambahan tinggi tanaman dari fase vegetatif menuju fase generatif diakibatkan oleh 
pertambahan ruas yang terjadi pada tanaman (Makarim dan Suhartatik, 2009). Tinggi tanaman yang diharapkan dalam pembentukan varietas ialah sama dengan varietas padi sawah yang dominan digunakan oleh masyarakat. Tanaman padi yang terlalu tinggi akan berpotensi untuk rebah, menyulitkan pemeliharaan serta tidak efisien ketika pemanenan. Menurut Norsalis (2011), tinggi tanaman varietas padi sawah secara umum berkisar antara $80-120 \mathrm{~cm}$.
Menurut Balai Besar Penelitian Padi (2010), tinggi tanaman varietas Inpari 13 yakni $\pm 120 \mathrm{~cm}$ dan varietas Ciherang yakni $107-115 \mathrm{~cm}$. Pada hasil penelitian, tinggi tanaman varietas pembanding lebih rendah apabila mengacu pada data tinggi tanaman padi menurut Balai Besar Penelitian Padi. Hal ini dapat disebabkan oleh faktor lingkungan yang juga mempengaruhi pertumbuhan tanaman padi.

Tabel 2. Rataan tinggi tanaman pada fase generatif, jumlah anakan produktif, umur berbunga, dan umur panen

\begin{tabular}{lcccc}
\hline \multicolumn{1}{c}{ Galur/Varietas } & $\begin{array}{c}\text { Tinggi Tanaman } \\
\text { Generatif }(\mathrm{cm})\end{array}$ & $\begin{array}{c}\text { Jumlah Anakan } \\
\text { Produktif }\end{array}$ & $\begin{array}{c}\text { Umur Berbunga } \\
(\text { HSS })\end{array}$ & $\begin{array}{c}\text { Umur Panen } \\
(\text { HSS })\end{array}$ \\
CG9-26-1-5 & $119.37 \mathrm{def}$ & $12.8 \mathrm{cdefg}$ & $83.0 \mathrm{a}$ & $112.0 \mathrm{a}$ \\
CG9-27-1-2 & $111.72 \mathrm{fgh}$ & $15.8 \mathrm{abc}$ & $83.0 \mathrm{a}$ & $112.0 \mathrm{a}$ \\
CG9-33-1-4 & $108.04 \mathrm{ghi}$ & $9.7 \mathrm{~g}$ & $77.7 \mathrm{~b}$ & $106.7 \mathrm{~b}$ \\
CG9-53-1-3 & $82.65 \mathrm{k}$ & $12.7 \mathrm{cdefg}$ & $74.0 \mathrm{c}$ & $103.0 \mathrm{c}$ \\
CG12-30-1-2 & $116.21 \mathrm{efg}$ & $11.7 \mathrm{efg}$ & $81.0 \mathrm{a}$ & $110.0 \mathrm{a}$ \\
CG12-30-1-3 & $120.28 \mathrm{cdef}$ & $10.9 \mathrm{fg}$ & $74.0 \mathrm{c}$ & $103.0 \mathrm{c}$ \\
HR2-6-1-1 & $107.31 \mathrm{ghi}$ & $15.3 \mathrm{bcd}$ & $77.7 \mathrm{~b}$ & $106.7 \mathrm{~b}$ \\
HR2-27-1-1 & $129.26 \mathrm{abcd}$ & $17.1 \mathrm{ab}$ & $81.0 \mathrm{a}$ & $110.0 \mathrm{a}$ \\
HR2-33-1-1 & $112.77 \mathrm{fgh}$ & $13.4 \mathrm{cdef}$ & $77.7 \mathrm{~b}$ & $106.7 \mathrm{~b}$ \\
HR3-6-2-1 & $100.03 \mathrm{ij}$ & $11.7 \mathrm{efg}$ & $74.0 \mathrm{c}$ & $103.0 \mathrm{c}$ \\
HR3-10-1-1 & $136.04 \mathrm{a}$ & $12.9 \mathrm{cdefg}$ & $77.7 \mathrm{~b}$ & $106.7 \mathrm{~b}$ \\
HR4-12-1-1 & $115.10 \mathrm{efgh}$ & $13.9 \mathrm{bcdef}$ & $75.3 \mathrm{c}$ & $104.3 \mathrm{c}$ \\
HR4-12-1-2 & $124.57 \mathrm{bcde}$ & $12.7 \mathrm{cdefg}$ & $77.7 \mathrm{~b}$ & $106.7 \mathrm{~b}$ \\
HR5-7-1-1 & $110.98 \mathrm{fgh}$ & $14.8 \mathrm{bcde}$ & $81.0 \mathrm{a}$ & $110.0 \mathrm{a}$ \\
HR5-9-1-1 & $113.99 \mathrm{efgh}$ & $15.9 \mathrm{abc}$ & $78.7 \mathrm{~b}$ & $107.7 \mathrm{~b}$ \\
HR5-9-4-1 & $98.67 \mathrm{ij}$ & $12.0 \mathrm{defg}$ & $81.0 \mathrm{a}$ & $110.0 \mathrm{a}$ \\
HR5-13-2-2 & $95.77 \mathrm{j}$ & $18.5 \mathrm{a}$ & $77.7 \mathrm{~b}$ & $106.7 \mathrm{~b}$ \\
HR6-5-1-1 & $130.55 \mathrm{abc}$ & $15.8 \mathrm{abc}$ & $74.0 \mathrm{c}$ & $103.0 \mathrm{c}$ \\
HR6-5-1-2 & $132.03 \mathrm{ab}$ & $15.3 \mathrm{bcd}$ & $81.0 \mathrm{a}$ & $110.0 \mathrm{a}$ \\
Inpari 13 & $104.37 \mathrm{hij}$ & $11.4 \mathrm{fg}$ & $81.0 \mathrm{a}$ & $110.0 \mathrm{a}$ \\
Ciherang & $112.09 \mathrm{fgh}$ & $16.1 \mathrm{abc}$ & $83.0 \mathrm{a}$ & $112.0 \mathrm{a}$ \\
\hline Keterangan : Angka yang diikuti 0 oleh huruf yang sama pada kolom yang sama menunjukkan tidak berbeda nyata berdasarkan uji & &
\end{tabular}

Pada Tabel 2 terdapat 8 galur dihaploid memiliki jumlah anakan produktif yang nyata lebih tinggi dibanding varietas Inpari 13 , namun tidak ada yang berbeda nyata lebih tinggi dari varietas Ciherang. Jumlah anakan padi menurut Deptan (2003) dikelompokkan ke dalam 5 kriteria, yaitu sangat sedikit ( $<5$ anakan), sedikit (5-9 anakan), sedang (10-19 anakan), banyak (2025 anakan), dan sangat banyak (>25 anakan). Jumlah anakan produktif selalu lebih kecil atau sama dengan jumlah anakan vegetatif.

Galur CG9-27-1-2, HR5-9-1-1, HR5-132-2, HR2-6-1-1, HR2-27-1-1, HR5-7-1-1, HR6-51-1, dan HR6-5-1-2 termasuk dalam kelompok padi dengan jumlah anakan sedang. Galur CG933-1-4 merupakan satu-satunya galur dihaploid yang termasuk dalam kelompok padi dengan jumlah anakan sedikit, sedangkan galur dihaploid yang lain dan dua varietas pembanding memiliki jumlah anakan sedang. Menurut Feng et al. (2007), jumlah anakan pada tanaman padi berbanding lurus dengan jumlah malai yang dihasilkan, namun jumlah anakan yang berlebihan dapat mengurangi bobot bulir setiap malai karena malai akan saling berkompetisi mendapatkan energi sinar matahari dan unsur hara.

Fase pembungaan ditandai dengan keluarnya bunga sekitar $50 \%$ dari setiap petak 
percobaan. Hasil pengamatan umur berbunga pada Tabel 2 menunjukkan bahwa terdapat 7 galur dihaploid yang memiliki umur berbunga yang tidak berbeda nyata dengan varietas Inpari 13 dan Ciherang. Galur CG9-53-1-3, CG12-30-1-3, HR36-2-1, dan HR6-5-1-1 memiliki umur berbunga paling singkat, yakni 74 hari. Rata-rata umur berbunga semua galur dihaploid dan varietas pembanding antara 74-83 hari setelah semai (HSS).

Berdasarkan penelitian Dewi et al. (2009), umur panen dapat dikelompokkan ke dalam sangat genjah ( $\mathrm{P} \leq 110 \mathrm{HSS})$, genjah $(110<\mathrm{P} \leq$ 115 HSS $)$, sedang (115< $\mathrm{P} \leq 125$ HSS $)$, dan dalam ( $\mathrm{P} \geq 125 \mathrm{HSS}$ ). Hasil pengamatan umur panen pada Tabel 2 menunjukkan bahwa terdapat 7 galur dihaploid yang memiliki umur panen yang tidak berbeda nyata dengan varietas Inpari 13 dan Ciherang. Galur CG9-53-1-3, CG12-30-1-3, HR36-2-1, dan HR6-5-1-1 memiliki umur panen yang berbeda nyata lebih cepat dari dua varietas pembanding, yakni 103 hari. Rata-rata umur panen semua galur dihaploid dan varietas pembanding antara 103-112 hari setelah semai (HSS). Galur CG9-26-1-5, CG9-27-1-2, dan varietas Ciherang merupakan padi dengan umur panen genjah, sedangkan varietas Inpari 13 dan 17 galur dihaploid lainnya adalah padi dengan umur panen sangat genjah.

\section{Panjang Malai, Jumlah Gabah Bernas, Gabah Hampa, dan Gabah Total}

Rata-rata panjang malai hasil pengamatan pada Tabel 3 antara 22,25-26,80 cm dan termasuk dalam kelompok malai pendek dan malai sedang. Galur HR3-10-1-1 merupakan galur dengan malai terpanjang diantara galur dihaploid lainnya dan varietas pembanding, namun tidak ada galur yang berbeda nyata lebih tinggi daripada dua varietas pembanding. Terdapat 12 galur dihaploid yang berbeda nyata lebih rendah dengan varietas Inpari 13 dan terdapat 11 galur dihaploid yang berbeda nyata lebih rendah dengan varietas Ciherang. Galur HR3-6-2-1 memiliki malai paling pendek diantara galur lainnya dan dua varietas pembanding. Panjang malai dikelompokkan dalam 3 kategori menurut Sajak et al. (2013), yakni malai pendek $(<25 \mathrm{~cm})$, malai sedang $(25-30$ $\mathrm{cm})$, dan malai panjang $(>30 \mathrm{~cm})$. Panjang malai diukur dari leher malai hingga ujung malai.

Tabel 3. Rataan panjang malai, jumlah gabah bernas, gabah hampa, dan gabah total

\begin{tabular}{lcccc}
\hline Galur/Varietas & Panjang Malai $(\mathrm{cm})$ & Gabah Bernas & Gabah Hampa & Gabah Total \\
\hline CG9-26-1-5 & $25.45 \mathrm{cdefg}$ & $134.4 \mathrm{~d}$ & $48.3 \mathrm{fgh}$ & $182.7 \mathrm{c}$ \\
CG9-27-1-2 & $26.44 \mathrm{ab}$ & $137.0 \mathrm{~cd}$ & $61.2 \mathrm{cde}$ & $198.2 \mathrm{a}$ \\
CG9-33-1-4 & $25.78 \mathrm{bcdef}$ & $123.2 \mathrm{e}$ & $73.4 \mathrm{~b}$ & $196.6 \mathrm{ab}$ \\
CG9-53-1-3 & $24.23 \mathrm{hi}$ & $116.2 \mathrm{f}$ & $51.8 \mathrm{efg}$ & $168.0 \mathrm{e}$ \\
CG12-30-1-2 & $25.37 \mathrm{defg}$ & $123.1 \mathrm{e}$ & $70.7 \mathrm{bc}$ & $193.8 \mathrm{ab}$ \\
CG12-30-1-3 & $24.75 \mathrm{gh}$ & $133.9 \mathrm{~d}$ & $33.5 \mathrm{jk}$ & $167.4 \mathrm{e}$ \\
HR2-6-1-1 & $23.46 \mathrm{i}$ & $94.7 \mathrm{j}$ & $34.4 \mathrm{ijk}$ & $129.1 \mathrm{~h}$ \\
HR2-27-1-1 & $23.49 \mathrm{i}$ & $104.4 \mathrm{ghi}$ & $39.6 \mathrm{hij}$ & $144.0 \mathrm{~g}$ \\
HR2-33-1-1 & $26.79 \mathrm{a}$ & $108.3 \mathrm{~g}$ & $22.0 \mathrm{l}$ & $130.2 \mathrm{~h}$ \\
HR3-6-2-1 & $22.25 \mathrm{j}$ & $105.0 \mathrm{gh}$ & $38.8 \mathrm{hij}$ & $143.7 \mathrm{~g}$ \\
HR3-10-1-1 & $26.80 \mathrm{a}$ & $98.3 \mathrm{j}$ & $87.7 \mathrm{a}$ & $186.0 \mathrm{bc}$ \\
HR4-12-1-1 & $24.91 \mathrm{fgh}$ & $142.1 \mathrm{bc}$ & $45.8 \mathrm{fghi}$ & $187.9 \mathrm{abc}$ \\
HR4-12-1-2 & $24.77 \mathrm{gh}$ & $117.2 \mathrm{f}$ & $39.3 \mathrm{hij}$ & $156.5 \mathrm{f}$ \\
HR5-7-1-1 & $25.41 \mathrm{cdefg}$ & $134.1 \mathrm{~d}$ & $43.2 \mathrm{ghij}$ & $177.3 \mathrm{cde}$ \\
HR5-9-1-1 & $25.21 \mathrm{efg}$ & $150.6 \mathrm{a}$ & $43.6 \mathrm{ghij}$ & $194.2 \mathrm{ab}$ \\
HR5-9-4-1 & $24.85 \mathrm{fgh}$ & $124.2 \mathrm{e}$ & $45.9 \mathrm{fghi}$ & $170.1 \mathrm{de}$ \\
HR5-13-2-2 & $25.95 \mathrm{abcde}$ & $144.7 \mathrm{~b}$ & $25.2 \mathrm{kl}$ & $170.0 \mathrm{de}$ \\
HR6-5-1-1 & $23.67 \mathrm{i}$ & $98.8 \mathrm{ij}$ & $71.8 \mathrm{bc}$ & $170.6 \mathrm{de}$ \\
HR6-5-1-2 & $23.98 \mathrm{hi}$ & $104.4 \mathrm{ghi}$ & $65.9 \mathrm{bcd}$ & $170.2 \mathrm{de}$ \\
Inpari 13 & 26.33 abc & $121.0 \mathrm{ef}$ & $59.5 \mathrm{de}$ & $180.6 \mathrm{cde}$ \\
Ciherang & $26.18 \mathrm{abcd}$ & $99.7 \mathrm{hij}$ & $56.5 \mathrm{def}$ & $156.2 \mathrm{f}$ \\
\hline Keterangan : Angka yang diikuti oleh huruf yang sama pada kolom yang sama menunjukkan tidak berbeda nyata berdasarkan uji & & &
\end{tabular}


Hasil pengamatan jumlah gabah bernas pada Tabel 3 menunjukkan bahwa galur HR5-9-11 memiliki jumlah gabah bernas terbanyak, sedangkan galur HR2-6-1-1 memiliki jumlah gabah bernas paling sedikit diantara galur dihaploid lainnya dan dua varietas pembanding. Terdapat 7 galur dihaploid yang memiliki jumlah gabah bernas nyata lebih tinggi dibandingkan varietas Inpari 13 dan sebanyak 13 galur dihaploid memiliki jumlah gabah bernas nyata lebih tinggi dibandingkan varietas Ciherang. Varietas Inpari 13 memiliki jumlah gabah bernas lebih banyak dibanding varietas Ciherang. Rata-rata jumlah gabah bernas sekitar 94.7-150.6 butir. Gabah bernas merupakan salah satu faktor yang dapat menentukan produktivitas. Semakin banyak jumlah gabah bernas per malai, maka produktivitas tanaman akan semakin tinggi (Siregar et al., 2013).

Galur HR3-10-1-1 memiliki jumlah gabah hampa terbanyak, sedangkan galur HR2-33-1-1 memiliki jumlah gabah hampa paling sedikit diantara dua varietas pembanding dan galur dihaploid lainnya (Tabel 3). Terdapat 4 galur dihaploid yang memiliki jumlah gabah hampa yang berbeda nyata lebih tinggi dibanding varietas Inpari 13 dan Ciherang. Jumlah gabah hampa seluruh galur dihaploid dan varietas pembanding sekitar 22.0-87.7 butir. Gabah hampa dapat disebabkan oleh banyak faktor seperti, kerebahan, serangan hama walang sangit, kurangnya intensitas cahaya, daun mengering dan serangan penyakit hawar daun bakteri, sehingga pengisian fotosintat pada bulir-bulir padi menjadi terhambat. Rata-rata gabah total per malai pada Tabel 3 berkisar antara 129.1-198.2 bulir. Galur CG927-1-2 memiliki jumlah gabah per malai paling banyak, sedangkan galur HR2-6-1-1 memiliki jumlah gabah per malai paling sedikit diantara dua varietas pembanding dan galur dihaploid lainnya. Terdapat 4 galur dihaploid yang memiliki jumlah gabah per malai nyata lebih tinggi dibandingkan varietas Inpari 13 dan sebanyak 14 galur dihaploid memiliki jumlah gabah per malai nyata lebih tinggi dibandingkan varietas Ciherang. Varietas Inpari 13 memiliki jumlah gabah per malai yang lebih banyak daripada varietas Ciherang.

Persentase Gabah Bernas, Persentase Gabah Hampa, Bobot 1000 butir, Produktivitas dan Tingkat Ketahanan terhadap Penyakit Hawar Daun Bakteri

Persentase gabah bernas tertinggi (Tabel 4) terdapat pada galur HR5-13-2-2, sedangkan persentase gabah bernas terendah adalah galur HR3-10-1-1. Terdapat 12 galur dihaploid yang memiliki persentase gabah bernas yang berbeda nyata lebih tinggi dibandingkan varietas Inpari 13 dan terdapat 14 galur dihaploid yang memiliki persentase gabah bernas yang berbeda nyata lebih tinggi dibandingkan varietas Ciherang. Rata-rata persentase gabah bernas seluruh galur dan dua varietas pembanding sekitar 52.9-85.2\%. Tanaman padi yang dinginkan saat ini adalah tanaman padi yang memiliki jumlah gabah bernas tinggi dan gabah hampa sedikit (Hasanah, 2007). $\mathrm{Hal}$ ini dapat dilihat dari persentase gabah bernas dan persentase gabah hampa pada tanaman padi.

Persentase gabah hampa tertinggi pada hasil pengamatan (Tabel 4) adalah galur HR3-101-1, sedangkan yang memiliki persentase gabah hampa terendah ialah galur HR5-13-2-2. Terdapat 3 galur dihaploid yang memiliki persentase gabah hampa yang berbeda nyata lebih tinggi daripada varietas Inpari 13 dan terdapat 2 galur dihaploid yang memiliki persentase gabah hampa yang berbeda nyata lebih tinggi daripada varietas Ciherang. Rata-rata persentase gabah hampa seluruh galur dan dua varietas pembanding sekitar $14.8-47.1 \%$.

Hasil pada Tabel 4 menunjukkan bahwa galur HR4-12-1-2 memiliki bobot 1000 butir terberat, sedangkan galur CG9-26-1-5 memiliki bobot 1000 butir terendah dibandingkan dua varietas pembanding dan galur dihaploid lainnya. Rata-rata bobot 1000 butir yang diperoleh berkisar 21.39-27.47 g. Terdapat 3 galur dihaploid yang memiliki bobot 1000 butir yang berbeda nyata lebih tinggi dibanding varietas Inpari 13 dan terdapat 6 galur dihaploid yang memiliki bobot 1 000 butir yang berbeda nyata lebih tinggi dibanding varietas Ciherang. Varietas Inpari 13 memiliki bobot 1000 butir yang lebih tinggi dibandingkan varietas Ciherang. Varietas Inpari 13 dan 6 galur dihaploid, yakni CG12-30-1-3, HR4-12-1-1, HR5-9-4-1, HR5-9-1-1, HR4-12-12, dan HR5-7-1-1 memiliki bobot 1000 butir dengan klasifikasi sedang. Varietas Ciherang dan 13 galur dihaploid lainnya memiliki bobot 1000 butir dengan klasifikasi bobot ringan. Pengklasifikasian bobot 1000 butir mengacu pada penelitian Sajak et al. (2013), yaitu kelas ringan $(<25 \mathrm{~g})$, sedang $(25-30 \mathrm{~g})$ dan berat $(>30 \mathrm{~g})$. Menurut Kadir (2011), bobot 1000 butir gabah bernas yang tinggi akan meningkatkan hasil gabah per satuan luas.

Produktivitas tertinggi dicapai oleh galur CG12-30-1-3, sedangkan produktivitas terendah dicapai oleh galur CG9-33-1-4 (Tabel 4) Galur CG12-30-1-3 dan HR3-10-1-1 memiliki produktivitas yang berbeda nyata lebih tinggi dibandingkan varietas Inpari 13 dan Ciherang. Varietas Inpari 13 memiliki produktivitas yang 
lebih tinggi dari varietas Ciherang, namun tidak berbeda nyata. Rata-rata produktivitas semua galur dihaploid dan dua varietas berkisar antara $2.50-4.94$ ton $\mathrm{ha}^{-1}$.

Tabel 4. Rataan persentase gabah bernas dan gabah hampa, bobot 1.000 butir, produktivitas dan ketahanan terhadap penyakit hawar daun bakteri

\begin{tabular}{lllllll}
\hline Galur/Varietas & $\begin{array}{c}\text { Persentase } \\
\text { Gabah } \\
\text { Bernas }(\%)\end{array}$ & $\begin{array}{c}\text { Persentase Gabah } \\
\text { Hampa }(\%)\end{array}$ & $\begin{array}{c}\text { Bobot } 1.000 \\
\text { Butir }(\mathrm{g})\end{array}$ & $\begin{array}{c}\text { Produktivitas } \\
\left.\text { (ton ha }{ }^{-1}\right)\end{array}$ & $\begin{array}{c}\text { Ketahanan terhadap } \\
\text { Hawar Daun } \\
\text { Bakteri }\end{array}$ \\
\hline CG9-26-1-5 & $73.9 \mathrm{def}$ & $26.1 \mathrm{fgh}$ & $21.39 \mathrm{e}$ & $3.37 \mathrm{bcde}$ & Tahan \\
CG9-27-1-2 & $69.1 \mathrm{fg}$ & $30.9 \mathrm{ef}$ & $21.63 \mathrm{e}$ & $2.91 \mathrm{de}$ & Agak Tahan \\
CG9-33-1-4 & $62.7 \mathrm{hi}$ & $37.3 \mathrm{~cd}$ & $22.67 \mathrm{~d}$ & $2.50 \mathrm{e}$ & Tahan \\
CG9-53-1-3 & $69.4 \mathrm{fg}$ & $30.6 \mathrm{ef}$ & $21.71 \mathrm{e}$ & $3.87 \mathrm{bcd}$ & Tahan \\
CG12-30-1-2 & $63.5 \mathrm{hi}$ & $36.5 \mathrm{~cd}$ & $21.92 \mathrm{de}$ & $3.13 \mathrm{cde}$ & Agak Tahan \\
CG12-30-1-3 & $80.1 \mathrm{bc}$ & $19.9 \mathrm{ij}$ & $27.35 \mathrm{a}$ & $4.94 \mathrm{a}$ & Tahan \\
HR2-6-1-1 & $73.4 \mathrm{def}$ & $26.6 \mathrm{fgh}$ & $24.73 \mathrm{c}$ & $3.58 \mathrm{bcd}$ & Tahan \\
HR2-27-1-1 & $72.5 \mathrm{ef}$ & $27.5 \mathrm{fg}$ & $24.33 \mathrm{c}$ & $3.29 \mathrm{bcde}$ & Agak Tahan \\
HR2-33-1-1 & $83.2 \mathrm{ab}$ & $16.8 \mathrm{jk}$ & $21.99 \mathrm{de}$ & $3.68 \mathrm{bcd}$ & Agak Tahan \\
HR3-6-2-1 & $73.0 \mathrm{def}$ & $27.0 \mathrm{fgh}$ & $22.11 \mathrm{de}$ & $3.95 \mathrm{bcd}$ & Tahan \\
HR3-10-1-1 & $52.9 \mathrm{k}$ & $47.1 \mathrm{a}$ & $21.95 \mathrm{de}$ & $4.28 \mathrm{ab}$ & Rentan \\
HR4-12-1-1 & $75.6 \mathrm{cde}$ & $24.4 \mathrm{ghi}$ & $26.87 \mathrm{ab}$ & $3.82 \mathrm{bcd}$ & Agak Rentan \\
HR4-12-1-2 & $74.9 \mathrm{de}$ & $25.1 \mathrm{gh}$ & $27.47 \mathrm{a}$ & $3.41 \mathrm{bcde}$ & Agak Rentan \\
HR5-7-1-1 & $75.6 \mathrm{cde}$ & $24.4 \mathrm{ghi}$ & $26.12 \mathrm{~b}$ & $4.05 \mathrm{abc}$ & Tahan \\
HR5-9-1-1 & $77.6 \mathrm{~cd}$ & $22.4 \mathrm{hi}$ & $27.10 \mathrm{a}$ & $3.97 \mathrm{bcd}$ & Tahan \\
HR5-9-4-1 & $73.0 \mathrm{def}$ & $27.0 \mathrm{fgh}$ & $26.83 \mathrm{ab}$ & $3.85 \mathrm{bcd}$ & Agak Tahan \\
HR5-13-2-2 & $85.2 \mathrm{a}$ & $14.8 \mathrm{k}$ & $24.81 \mathrm{c}$ & $3.93 \mathrm{bcd}$ & Agak Rentan \\
HR6-5-1-1 & $57.9 \mathrm{j}$ & $42.1 \mathrm{~b}$ & $24.48 \mathrm{c}$ & $3.45 \mathrm{bcde}$ & Rentan \\
HR6-5-1-2 & $61.5 \mathrm{ij}$ & $38.5 \mathrm{bc}$ & $24.38 \mathrm{c}$ & $3.06 \mathrm{cde}$ & Rentan \\
Inpari 13 & $67.0 \mathrm{gh}$ & $33.0 \mathrm{de}$ & $26.10 \mathrm{~b}$ & $3.19 \mathrm{cde}$ & Agak Rentan \\
Ciherang & $63.8 \mathrm{hi}$ & $36.2 \mathrm{~cd}$ & $24.70 \mathrm{c}$ & $3.20 \mathrm{cde}$ & Agak Tahan \\
\hline Keterangan : Angka yang diikuti oleh huruf yang sama pada kolom yang sama menunjukkan tidak berbeda nyata berdasarkan uji \\
DMRT pada taraf $5 \%$ & & & & \\
& & & & &
\end{tabular}

Galur CG12-30-1-3 yang memiliki produktivitas tertinggi karena jumlah gabah bernas dan gabah total per malai yang tinggi serta bobot 1000 butir seberat $27.35 \mathrm{~g}$. Galur ini juga tahan terhadap penyakit hawar daun bakteri. Galur HR5-7-1-1 dengan produktivitas tertinggi ketiga juga memiliki jumlah gabah bernas yang tidak berbeda nyata dengan galur CG12-30-1-3 serta memiliki jumlah anakan produktif dan tinggi tanaman yang sedang. Persentase gabah bernasnya pun tinggi yakni $75.6 \%$ dengan bobot 1000 butir seberat 26.12 g. Galur HR5-9-1-1, HR5-13-2-2, dan HR3-6-2-1 memiliki produktivitas tinggi karena persentase bernasnya yang tinggi. Galur HR5-9-1-1 memiliki jumlah gabah bernas tertinggi dengan jumlah anakan 15.9 dan bobot 1 000 butir seberat 27.10 g. Galur HR5-13-2-2 dengan persentase gabah bernas tertinggi memiliki jumlah gabah bernas yang tinggi pula. Galur HR3-10-1-1 memiliki produktivitas tertinggi kedua, meskipun jumlah gabah bernas dan persentase gabah bernas kecil. Galur ini memiliki jumlah gabah total yang tinggi yakni 186 butir. Menurut Akhmadi (2015), karakter komponen hasil yang memiliki keeratan hubungan dengan karakter hasil adalah tinggi tanaman generatif, jumlah gabah bernas per malai, jumlah gabah total per malai, dan bobot 1000 butir.

Terdapat 8 galur dihaploid yang tahan terhadap penyakit hawar daun bakteri. Varietas Ciherang, galur CG9-27-1-2, CG12-30-1-2, HR227-1-1, HR2-33-1-1, dan HR5-9-4-1 termasuk dalam kategori agak tahan terhadap penyakit hawar daun bakteri. Varietas Inpari 13 agak rentan terhadap penyakit hawar daun bakteri, seperti galur HR4-12-1-1, HR4-12-1-2, dan HR5-13-2-2. Galur HR3-10-1-1, HR6-5-1-1, dan HR6-5-1-2 merupakan galur haploid yang rentan terhadap penyakit hawar daun bakteri. 


\section{KESIMPULAN}

Galur CG12-30-1-3 merupakan galur dengan produktivitas tertinggi (4.94 ton $\mathrm{ha}^{-1}$ ) karena jumlah gabah bernas dan gabah total per malai tinggi serta bobot 1000 butir yang berat yakni 27.35 g. Galur HR5-7-1-1 dan HR3-10-1-1 memiliki produktivitas lebih dari 4 ton $\mathrm{ha}^{-1}$, namun galur HR3-10-1-1 rentan terhadap penyakit hawar daun bakteri serta memiliki bobot 1000 butir yang rendah. Galur CG9-53-1-3, HR26-1-1, HR2-33-1-1, HR3-6-2-1, HR4-12-1-1, HR5-7-1-1, HR5-9-1-1, HR5-9-4-1, dan HR5-132-2 memiliki produktivitas lebih dari 3.5 ton $\mathrm{ha}^{-1}$, namun galur HR4-12-1-1 dan HR5-13-2-2 agak rentan terhadap penyakit hawar daun bakteri, sedangkan HR2-33-1-1 dan HR5-9-4-1 agak tahan terhadap penyakit hawar daun bakteri. Terdapat beberapa galur yang tahan terhadap penyakit hawar daun bakteri, diantaranya galur CG9-26-15, CG9-33-1-4, CG9-53-1-3, HR2-6-1-1, HR3-62-1, HR5-7-1-1 dan HR5-9-1-1, namun galur CG9-33-1-4 memiliki produktivitas paling rendah.

\section{DAFTAR PUSTAKA}

Abdullah, B., Tjokrowidjojo, S., Sularjo. 2008. Perkembangan dan prospek perakitan padi tipe baru Indonesia. Jurnal Litbang Pertanian. 27 (1):1-9.

Akhmadi, G. 2015. Seleksi dan analisis interaksi genotipe dan lingkungan galur-galur padi dihaploid hasil kultur antera. [Tesis]. Institut Pertanian Bogor. Bogor.

Anindyajati, A.D. 2015. Pengujian pendahuluan galur-galur dihaploid generasi pertama (DH0) padi sawah. [Skripsi]. Institut Pertanian Bogor. Bogor.

Badan Karantina Tumbuhan. 2007. Standar Pelayanan Pengujian Organisme Pengganggu Tumbuhan. Badan Karantina Tumbuhan.

[BB Padi] Balai Besar Penelitian Tanaman Padi. 2014. Varietas Padi Gogo. [internet]. [diunduh 2014 Mei 26]. Tersedia pada http://bbpadi.litbang.deptan.go.id/index.p $\mathrm{hp} / \mathrm{in} /$ varietas-padi-gogo.

[BB Padi] Balai Besar Penelitian Tanaman Padi. 2010. Pedoman Utama IP Padi 400. Badan Penelitian dan Pengembangan Pertanian. Subang.
[Deptan] Departemen Pertanian Balai Penelitian dan Pengembangan Pertanian Komisi Nasional Plasma Nutfah. 2003. Panduan Sistem Karakterisasi dan Evaluasi Tanaman Padi. Departemen Pertanian. Jakarta.

Dewi, I.S., Purwoko, B.S. 2001. Kultur antera untuk mendukung program pemuliaan tanaman padi. Bul. Agron. 29(2):59-63.

Dewi, I.S., Purwoko, B.S. 2011. Kultur in vitro untuk produksi tanaman haploid androgenik. [dalam] G.A. Wattimena, N.A. Mattjik, N.M. Armini W., A. Purwito, D. Effendi, B.S. Purwoko, N. Khumaida, editor. Bioteknologi dalam Pemuliaan Tanaman. Ed ke-1. Bogor (ID): IPB Press.

Dewi, I.S., Purwoko, B.S. 2012. Kultur antera untuk percepatan perakitan varietas padi di Indonesia. J.AgroBiogen. 8(2):78-88.

Dewi, I.S., Purwoko, B.S., Aswidinnoor, H., Somantri, I.H. 2004. Kultur antera padi pada beberapa formulasi media yang mengandung poliamin. Jurnal Bioteknologi Pertanian. 9(1):14-19.

Dewi, I.S., Purwoko, B.S., Aswidinnoor, H., Somantri, I.H., Chozin, M.A. 2005. Regenerasi tanaman pada kultur anter beberapa aksesi padi indica toleran aluminium. J.AgroBiogen. 2(1):30-35.

Dewi, I.S., Trilaksana, A.C., Trikoesoemaningtyas, Purwoko, B.S. 2009. Karakterisasi galur haploid ganda hasil kultur antera padi. Buletin Plasma Nutfah. 15(1):1-12.

Feng, W., Cheng, F., Zhang, G. 2007. Difference in grain yield and quality among tillers in rice genotypes differing in tillering capacity. Rice Science. 14(2):135-140.

Gunarsih, C. 2015. Pembentukan galur-galur dihaploid padi sawah tadah hujan toleran kekeringan melalui kultur antera. [Tesis]. Institut Pertanian Bogor. Bogor.

Hasanah, I. 2007. Bercocok Tanam Padi. Jakarta (ID): Azka Mulia Media. 
[IRRI] International Risk Research Institute. 1996. Standard Evaluation System for Rice. International Rice Institut Los Banos, Philippines. Manila.

Kadir, A. 2011. Responsi genotipe padi mutan hasil iradiasi sinar gamma terhadap cekaman kekeringan. J. Agrivigor. 10(3):235-246.

[Kementan] Kementerian Pertanian Republik Indonesia. 2014. Pusat Data Pertanian. [internet]. [diunduh 2014 Mei 07]. Tersedia pada http:/www.deptan.go.id/infoeksekutif/tan/ isi_infoekse_tan.htm.

Khaeruni, A. 2001. Penyakit Hawar Daun Bakteri pada Padi : Masalah dan Upaya Pemecahannya. Bogor (ID): IPB Press.

Khafiya, N. 2015. Pengujian daya hasil pendahuluan galur-galur padi sawah (Oryza sativa) hasil kultur antera. [Skripsi]. Institut Pertanian Bogor. Bogor.

Makarim, A.K., Suhartatik, E. 2009. Morfologi dan fisiologi tanaman padi. Di dalam: Suyamto, Widiarta I.N., Satoto, editor. Padi: Inovasi Teknologi dan Ketahanan Pangan. Ed ke-1. Jakarta (ID): LIPI Press.

Mangoendidjojo, W. 2003. Dasar-dasar pemuliaan tanaman. Jakarta (ID): Kanisius.

Norsalis, E. 2011. Padi sawah dan padi gogo [artikel publikasi]. Universitas Airlangga. Surabaya.

[Puslitbangtan] Pusat Penelitian dan Pengembangan Tanaman Pangan. 1993.
Deskripsi Varietas Unggul Palawija. Pusat Penelitian dan Pengembangan Tanaman Pangan, Badan Penelitian dan Pengembangan Pertanian Departemen Pertanian. Bogor.

Putri, N.H. 2014. Produksi tanaman dihaploid dari persilangan padi sawah dan padi gogo melalui kultur anter. [Skripsi]. Institut Pertanian Bogor. Bogor.

Sajak, A., Masniawati, A., Juhriah, Tambaru, E. 2013. Karakter morfologi plasma nutfah padi lokal asal Kabupaten Tana Toraja Utara. Sulawesi Selatan [artikel publikasi]. Universitas Hasanuddin. Makasar.

Satoto, Daradjat, A.A., Wahyuni, S. 2008. Varietas Unggul Padi Sawah: Pengertian dan Aspek Terkait. Informasi Ringkas Bank Pengetahuan Padi Indonesia.

Satoto, Sutaryo, B., Suprihatno, B. 2009. Prospek Pengembangan Padi Hibrida. Sukamandi. Balai Besar Penelitian Tanaman Padi. Subang.

Siregar, D., Marbun, P., Marpaung, P. 2013. Pengaruh varietas dan bahan organik yang berbeda terhadap bobot 1000 butir dan biomassa padi sawah IP 400 pada musim tanam I. Jurnal Online Agroteknologi. 1(4):1413-1421.

Susanto, U., Drajat, A.A., Suprihatno, B. 2003. Perkembangan pemuliaan padi sawah di Indonesia. Jurnal Litbang Pertanian. 22(3):128-129. 